l'exécution d'un programme de dépouillement de grammaires bantoues à la Section de Linguistique du Musée Royal de l'Afrique Centrale, Tervuren. Cette subvention prévoyait deux chercheurs travaillant pendant deux ans à temps plein, sous la direction de M. A. E. Meeussen, chef de la Section, dont émanait le projet. Le programme fut baptisé 'Lolemi' ('langue' en proto-bantou). Les travaux en sont assumés actuellement par un chercheur à temps plein et deux à mi-temps, les disponibilités de chacun devant être prises en considération. Le travail consiste en (I) dépouillement grammatical par langue, (2) études d'un point particulier de grammaire dans tout le domaine bantou, et (3) accessoirement, travail avec des informateurs.

\title{
African Studies in Leeds
}

LEEDs Inter-Departmental African Studies Unit, with a Standing Committee of which Mr. W. T. Newlyn (Lecturer in Economics) is the Executive Officer, proposes to issue a biennial Bulletin of both internal and general news in the field of African Studies. The University has made a number of grants for field research and of secondments of academic staff for work in Africa.

\section{Centre 'Europe-Afrique' Columbianum}

LA première manifestation concrète du Centre 'Europe-Afrique', de l'Institut d'Études Columbianum, était la réunion à Gênes du 21 au 30 janvier I965 d'une Table Ronde sur la culture négro-africaine et ses expressions cinématographiques en Afrique, Amérique Latine, et Amérique du Nord, sous le patronage de l'UNESCO.

\section{Second Editions and Reprints}

THE second edition of Classical African Sculpture by Margaret Trowell (London: Faber, $1964,36 s$.) has been revised to bring it up to date in regard to the names of the African territories which have become independent during the last few years. It also includes some account of Mr. Bernard Fagg's work on the early Nok culture, and on the chronological arrangement of the bronzes from Benin and neighbouring sources by Mr. William Fagg. The bibliography has also been extended and revised.

Constitutional Developments in Nigeria, by Kalu Ezera, was first published in 1960. The new edition (London: Cambridge University Press, 1964, 30s.) contains a substantial new chapter on Independent Nigeria, 1960-3, covering the period immediately before independence and the three years following.

Lady Lugard's $A$ Tropical Dependency has recently been reprinted by Frank Cass (London, 1964, 65s.). This outline of the history of the Western Sudan and account of the settlement of Northern Nigeria was first published in 1906.

\section{African Invention Myths}

Mr. George Bennett, of the Institute of Commonwealth Studies, Oxford, writes:

At Mbale in eastern Uganda in 1953 I was asked over dinner one evening by a European who was a travelling lecturer in those parts if I had ever heard 'the bicycle story', which he assured me he had met in a number of places in East Africa. The story claims that it was an African who invented the bicycle. The Europeans who saw it thought it a good idea and took steps to suppress the inventor by, according to various versions of the story, putting him in prison, cutting off his legs, \&cc. They then took the idea to England where they manufactured the bicycle and have been selling models to Africans at great profit ever since. In I954 I myself heard a similar story in Kumasi, the Ashanti capital. There, after lecturing 